\title{
Pânico e terror: a presença da cólera na Província do Espírito Santo (1855-1856)
}

Panic and terror: the presence of cholera in the Province of Espirito Santo (1855-1856)

\author{
Sebastião Pimentel Franco \\ Professor Associado IV no \\ Departamento de História da \\ Universidade Federal do Espírito \\ Santo (UFES - Vitória/Brasil) \\ email:sp.franco@uol.com.br
}

\begin{abstract}
Resumo
Investiga como, em determinado período da História da Medicina, no Espírito Santo, diferentes agentes (legisladores, administradores, médicos, curandeiros e população em geral) lidaram com a passagem de epidemias, verificando as mudanças e permanências, as atitudes e respostas que as moléstias geraram, em particular a cólera. Ao realizar uma investigação na perspectiva da nova História da Medicina, busca evidenciar a vida social, política, econômica e cultural dos grupos humanos a partir da ocorrência de enfermidades individuais ou coletivas. Utiliza como fonte a documentação oficial (correspondências da administração, resoluções, petições, requerimentos, relatórios de governo) e a mídia impressa.
\end{abstract}

\begin{abstract}
This is an investigation about how, in a certain period of the History of Medicine in Espírito Santo, different actors (legislators, administrators, doctors, healers and the general public) dealt with the surge of epidemics, by verifying the changes and continuities, the attitudes and responses that diseases, particularly cholera, have generated. When conducting an investigation in the light of the new History of Medicine, it seeks to show the social, political, economic and cultural human groups from the occurrence of individual or collective sickness. The sources used were official documents (administrative mail, resolutions, petitions, legal requests, government reports) and printed media.
\end{abstract}

Palavras-Chave

Epidemias. História da Saúde. Espírito Santo. Século XIX. Cólera.

Keywords

Epidemics. History of Health. Espírito Santo. 19 ${ }^{\text {th }}$ century. Cholera. 
1

BELTRÃO, Jane Felipe. Cólera, o flagelo do Belém do Grão Pará. 1999. 260 f. Tese (Doutorado em História). Programa de Pós-Graduação em História da Universidade Estadual de Campinas, Campinas/SP. 1999

LE ROY Lauderie, E. Um conceito: a unificação microbiana do mundo (séculos XIV-XVII). In: Le territoire de I'historien. Paris: Gallimard, 1978.

3

WITTER, Nikelem Acosta. Males e epidemias: sofredores, governantes e curadores no sul do Brasil (Rio Grande do Sul, século XIX). 2007. 276 f. Tese (Doutorado em História). Programa de Pós-Graduação em História, Universidade Federal Fluminense, Niterói/RJ. 2007.

4

Idem. p. 39.

Falla com que o presidente da Província do Espirito Santo se dirigiu à Assembleia Legislativa Provincial no dia $1^{\circ}$ de abril de 1840 . Rio de Janeiro: [s.n.], 1840. (Fizemos opção por utilizar a referência das fontes na sua grafia original).
Foi no século XIX que as epidemias, de forma avassaladora, percorreram todos os continentes, dizimando um grande número de pessoas.

Este artigo busca evidenciar um desses surtos epidêmicos, a cólera, que ocorreu na Província do Espírito Santo entre 1855 e 1856. Para tanto, este texto foi concebido na perspectiva da História da Medicina ou da História da Saúde. Ao alargar o conceito de saúde e de doença, passamos a nos debruçar sobre o exame dos surtos epidêmicos.'

Utilizamos como fonte a documentação produzida pela administração imperial, como resoluções, petições, requerimentos, correspondências expedidas e recebidas por presidentes e vice-presidentes da província, correspondências da Inspetoria de Higiene Pública, relatórios de saúde pública encaminhados à Assembleia Legislativa Provincial, relatórios e falas de governantes apresentados à Assembleia Legislativa Provincial por ocasião de suas posses ou entrega do cargo da chefia da província, documentação esta existente no Arquivo Público Estadual do Espírito Santo. Também utilizamos o jornal Correio da Victória.

\section{0 século XIX e os surtos epidêmicos}

Se os surtos epidêmicos ocorreram de forma ocasional no período colonial, a partir do século XIX, houve uma tendência do aumento das epidemias. Surtos epidêmicos de febre amarela, malária, varíola, cólera, além de outras doenças, espalharam-se pelo país, atingindo todas as regiões de forma indistinta, provocando pânico e terror, dizimando significativo número de pessoas e alterando costumes enraizados na sociedade.

Fica, então, a pergunta: por que, a partir do século $\mathrm{XIX}$, houve um aumento dos surtos epidêmicos?

Os estudiosos da História da Medicina são unânimes em apontar que a proliferação dos surtos epidêmicos se deu em razão da forte presença militar e da expansão comercial maritima inglesa na İndia e na Ásia. Para Le Roy Lauderie, ${ }^{2}$ as transações comerciais do Império Britânico levaram o mundo a uma globalização e, como consequência, efetuaram a unificação microbiana.

Da mesma forma pensa Nikelen Acosta Witter, ${ }^{3}$ ao dizer que a força motriz que impulsionou o surgimento e propagação global de moléstias foi o aumento de circulação de gentes e mercadorias.

É bom destacar que não apenas o expansionismo militar e comercial foram os responsáveis por esse fenômeno. Witter ${ }^{4}$ diz ainda que "[...] possibilidades de ordem natural [ligadas à modificação da natureza], como uma mutação [de embriões], ou mudança climática," não podem ser descartadas como motivos da disseminação de surtos epidêmicos.

$\mathrm{Na}$ Província do Espírito Santo, antes do aparecimento desses surtos epidêmicos de grande proporção, como a febre amarela e a cólera, outras doenças incomodavam a população, levando a óbito um razoável número de pessoas, o que já provocava preocupação das autoridades governamentais.

Em 1840, a presença de febres intermitentes causou muitas mortes em São Mateus, preocupando o governante da província, levando-o a solicitar ao cirurgião vacínico que lhe informasse as causas desse mal. Este responde explicando que as origens dessa doença era o fato de a população estar inalando ar pútrido dos pântanos, consumindo água insalubre, o pouco asseio do povo e, por fim, aponta ainda, a ingestão de alimentos salgados e o uso de bebidas alcóolicas. ${ }^{5}$

Até julho de 1850, não se tinha notícias de grandes epidemias no Espírito Santo, pois, segundo o presidente da província: 
Relatório com que Felippe José Pereira Leal, presidente da Província do Espírito Santo, abriu a sessão ordinária da respectiva Assembleia Legislativa, no dia de 25 de julho do corrente ano. Victoria: Typographia Capitaniense de P.A. d'Azeredo, 1850. p. 28.

Relatório com que Felippe José Pereira Leal, presidente da Província do Espírito Santo, abriu a sessão ordinária da respectiva Assembleia Legislativa, no dia 23 de maio do corrente ano. Victoria: Typographia Capitaniense de P. A. d'Azeredo, 1851. p. 15.

8

SERAFIM, Patricia Rodolfo. As epidemias que grassaram no Brasil e no Espírito Santo, durante o século XIX, entre os anos 1840 e 1860. 2002. Monografia (Conclusão de Curso de Graduação em História). Departamento de História, Universidade Federal do Espírito Santo, Vitória, 2002.

APE/ES. Fundo Governadoria. Livro 202. Correspondência do presidente da Província do Espírito Santo, Sebastião Machado Nunes, ao ministro secretário de Estado dos Negócios do Império, Luiz Pedreira do Coutto Ferraz, datada de 15 de dezembro de 1855, enviando o relatório produzido pelos médicos sobre a situação da província em face à ocorrência da cólera. Infelizmente não conseguimos encontrar no arquivo pesquisado o conteúdo do relatório.

10

EUGENIO, Allison. Fragilidade pública em face das epidemias na segunda metade do século XIX. Revista Varia História, n. 32, jul./2004, p. 211-234.

11

Relatorio que o presidente da Província do Espírito Santo, José Maurício Fernandes Pereira de Barros, aprsentou na abertura d Assembleia Legislativa Provincial, em 23 de maio de 1856. Victoria: Typographia Capitaniense de P. A d'Azeredo, 1856. Essas Comissões foram criadas por um ato único.
A excepção das bexigas, que fizerão algumas víctimas na Villa de Itapemirim, nem-uma, outra moléstia de caracter epidêmico tem accomettido a província, que sempre salubre, não foi visitada graças à Providencia, pela febre amarella, que tantas vidas ceifou na Côrte, Bahia, Pernambuco, e que continua em outras províncias violenta e avassaladora. ${ }^{6}$

Entretanto, em 1850, o presidente da província relata que, como estava ocorrendo em outras províncias litorâneas do Brasil, a febre amarela se manifestou. Na capital, Vitória, ela fez "[...] desastroza residência por quase cinco meses consecutivos, causando estragos, promovendo o lucto e a tristeza, e ceifando em toda a província mais de 200 vidas." $^{7}$

Em seu trabalho monográfico, Patricia Rodolfo Serafim ${ }^{8}$ afirma que, em razão do aparecimento da febre amarela, o Governo Imperial teve que tomar providências, entre elas, nomeou os médicos comissionados, João José Vieira e José Joaquim Rodrigues, que vieram da Bahia para o Espírito Santo. Esses dois médicos, formados pela Escola de Medicina da Bahia, segundo relato do presidente da província ${ }^{9}$ teriam vindo observar o flagelo que se fazia presente na província, uma vez que apresentaram relatório sobre o que encontraram durante a passagem da epidemia de cólera. Prova cabal de que esses médicos só vieram realizar inspeção é o fato de não termos encontrado na documentação coligida nenhuma referência à atuação sistemática desses médicos nem a pagamento de gratificação por atuarem no combate ao mal epidêmico.

A atitude do Governo Provincial, na tentativa de solucionar o problema que afligia a população do Espírito Santo, já nos deixa entrever que, embora não existisse ainda uma política pública para saúde, a população não estava entregue à própria sorte e recebia, sim, algum tipo de assistência. Nesse sentido, Alisson Eugenio diz que "[...] quase sempre, quando as enfermidades já estavam batendo às portas das pessoas, ou já se encontravam em seus lares [...], uma certa proteção pública passou a ser solicitada para [elas], como forma de impedir as marchas das epidemias que tanto atormentavam"10 a população.

A própria criação das Comissões Sanitárias, que foram instituídas logo após o aparecimento da epidemia de cólera na província, demonstra que o Estado, apesar de todas as limitações, se preocupava com a assistência à população. 0 presidente da província, ao tomar conhecimento de que o surto da cólera se aproximava, criou Comissões Sanitárias para que ações efetivas fossem concretizadas, evitando a chegada ou o alastramento da doença. Nesse sentido, ainda em novembro, nomeou Comissões Sanitárias para as localidades: Vitória(capital), Itapemirim, Piúma, Benevente, Serra, Gurapari, Espírito Santo (Vila Velha), Viana, Cariacica, Benevente (Anchieta), Carapina, Barra e para a cidade de São Mateus. ${ }^{11}$

Essas Comissões em geral eram constituídas por indivíduos de certo poder aquisitivo, em sua maioria eram alfabetizadas e partícipes da estrutura do poder, religioso, militar ou civil. Conseguimos identificar, entre os membros dessas, dez religiosos (8 vigários e 2 freis), sete militares (4 capitães, 2 majores e 1 tenente coronel) três doutores ( 2 advogados e 1 engenheiro), um médico, um boticário, quatro professores primários e oito comerciantes.

\section{A chegada da cólera}

De todos os surtos epidêmicos ocorridos na Província do Espírito Santo no século XIX, o que causou maior pavor à população local foi a cólera, tanto pelo número de mortes, como pelo completo desconhecimento da doença e ainda pelo imaginário que ela causava à população. 
EVANS, Richard. Epidemias and revolution: cholera in nineteenthcentury. Europ. Manchester: Part\&tPresente, 1988.

13

BELTRÃO, Jane Felipe. Op. Cit.

14

DAVID, Onildo Reis. 0 inimigo invisivel: epidemia na Bahia no século XIX. Salvador: Ufba, 1996.

15

SANTOS, Luiz Antonio de Castro. Um século de cólera: itinerário do medo. Physis-Revista de Saúde Coletiva, Vol. 4, n. 1, 1994. p. 81.

16

SANJAD, Nelson. Cólera e medicina ambiental no manuscrito "cholera-mórbus" (1832), de Antonio Correia de Lacerda (1777-1852). Revista História Ciências, Saúde. Rio de Janeiro, Vol. 11, n. 3, setdez./2004. p. 587-618

DAVID, Onildo Reis. 0p. Cit. p. 53
A região do Baixo-Bengala, na Índia, é tida, pela historiografia, como o local onde apareceu a cólera.

Embora essa epidemia tenha chegado com grande intensidade na Europa somente no século XIX, é possível afirmar que o Ocidente conhecia essa doença desde a intensificação dos contatos comerciais entre o 0cidente e o Oriente, já no século XV.

Segundo Richards Evans, ${ }_{1}^{12}$ o avanço da cólera no mundo deu-se entre 1817 e 1824, partindo da Índia em direção à China, depois alcançando o Japão, chegando até mesmo ao continente africano. Entre 1829 e 1837, ocorre outro surto da doença, que chega à Inglaterra e países do continente americano. Em 1831, a cólera se espalha por países como a Rússia, a Polônia, a França e a Alemanha. Entre 1840 e 1860, ocorre um novo surto da doença, considerado de maior mortalidade, tendo atingido, inclusive, o Brasil.

Para Beltrão, ${ }^{13}$ a cólera chega ao Brasil via Portugal, em 1855, em Belém do Pará, quando operários portugueses que vieram trabalhar naquela localidade contraíram a doença, durante a viagem do navio Defensor, vindo a falecer quando chegaram. Do Pará, a epidemia se espalha para o Amazonas e o Maranhão. De lá, sabe-se que se dirigiu para a Bahia, segundo Onildo Reis David. ${ }^{14}$ Da Bahia, a cólera se expandiu por toda a região hoje chamada de Nordeste, atingindo Alagoas, Pernambuco, Ceará, Paraiba e Sergipe. Estendese por outras regiões como o Sul do Brasil, principalmente o Rio Grande Sul, e ainda o Sudeste, atingindo o Rio de Janeiro e o Espírito Santo.

\section{0 conhecimento da cólera}

Embora não se soubessem com exatidão as causas de tal doença, já desde a Grécia antiga, o médico Hipócrates, no século $V$ a.C, apontava como possivel causa da cólera os miasmas ou "[...] emanações exaladas por águas estagnadas, cadáveres ou qualquer matéria em decomposição."15

Mesmo no século XIX, a própria ciência médica não tinha uma percep ção única sobre as causas dessa doença. Para Nelson Sanjad, ${ }_{1}^{16}$ os homens do século XIX atribuíam inúmeros motivos como possíveis propagadoras da moléstia, entre eles, os desregramentos, a má alimentação, o excesso de trabalho, a exposição exagerada à umidade ou mudança climática, as paixões deprimentes. Entretanto, a atmosfera tinha papel fundamental, sem a qual, segundo se pensava, os surtos epidêmicos não ocorriam.

Acreditava-se que a cólera advinha dos miasmas, ou seja, gases pútridos que se espalhavam pela atmosfera "[...] cuja presença podia ser aferida por diversos tipos de fedor." ${ }^{17}$ Esses gases originavam-se da decomposição de matéria orgânica encontrada nos montes de lixo existentes nas ruas, valas, esgotos, matadouros, chiqueiros de porcos, peixarias, curtumes e igrejas, onde se enterravam os mortos.

Embora a teoria contagionista tivesse prevalecido no Brasil como um todo e no Espírito Santo em particular, pensamento divergente esteve presente, como nos aponta Sidney Challoub, como a corrente médica que credita o aparecimento dos males epidêmicos ao infeccionismo. Diferenciando essas duas corrente, o mesmo autor diz que, para os contagionistas, 0 ar pútrido era o responsável pelo aparecimento das doenças, que eram transmitidas de pessoa a pessoa diretamente, por contato físico, por toque de objetos contaminados ou, ainda, pela respiração do ar que as circundava. Os infeccionistas acreditavam que as doenças eram transmitidas de um indivíduo doente para outro são, "[...] contudo tal processo não ocorria propriamente por contágio: 0 indivíduo doente age sobre o são ao alterar 0 
CHALLOUB, Sidney. Cidade febril: cortiços e epidemias na Corte imperial. Rio de Janeiro: Companhia das Letras, 1996. p. 64 ar ambiente que os circundava [..], ou seja, a infecção se devia à ação que substâncias animais e vegetais em putrefação exerciam no ar ambiente."18

Mesmo pouco se conhecendo sobre a doença, esta era diagnosticada pelos seguintes sintomas: sensação de mal-estar indefinido, que evoluía para um abatimento e prostração, seguidos de falta de apetite, dores no

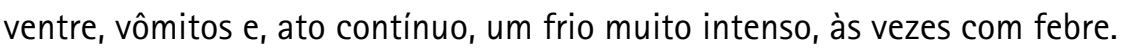
Quanto à pulsação, ficava lenta, sofria o doente também asfixia, uma sede insaciável e a pele adquiria um tom azulado.

0 Jornal Correio da Victoria descrevia os sintomas da cólera, dividindo a doença em estágios, que seriam os seguintes:

Os primeiros signaes precursores do cholera são ordinariamente: moleza, pallidez da face e dos lábios, contracção e pressão no estomago, mãos frias, sensação de enfraquecimento e topor dos dedos, pés frios e pezados disposição à diarrehéa, com defecções liquidas esverdeadas. [Num segundo momento] cahida rapida de todas as forças vitaes, impossibilidade de conservar-se em pé, ar perturbado, olhos encovados, lingua fria, frio glacial e côr azulada das mãos, da face e mesmo de todo o corpo, desanimo e desespero, oppressão do peito e do coração com grande angustia e temor de suffocar-se; cabeça tomada, entorpecimento do cérebro e dos nervos cerebrais, gritos e gemidos com voz profunda e rouca, dor ardente no estomago e na garganta, câimbras ou dores tractivas nas barrigas das pernas e em outrás partes musculosas; sensibilidade mui dolorosa na bocca do estomago ao tocar; muitas vezes auzencia de sede, de vômitos e diarrehéa, muitas vezes evacuações aasaz freqüentes superior e inferiormente.[Evoluiria para] Vertigens, desmaios freqüentes, diminuição do tacto, do ouvido, e da vista, angustia, temor da morte, grande agitação, frio glacial de todo o corpo pollidez cadaverosa da face, olhos encovados, amorteados, semi-fechados, vista exprimindo o soffrimento, ar pensativo, lábios azulados, sede excessiva, inextinguivel, desejo de bebidas frias, calor ardente na garganta, vomito ao principio doa alimentos ingeridos depois de matérias que, de mucozar e beliosas que são no começo, tornão-se logo leitozas ou semelhante a água de arroz, pressão e dores nos intestinos, voz fraca, enrouquecida, oppressão dolorosa no peito, do estomago e da região pre-cordial, respiração curta, câimbras ao principio nas extremidades inferiores, propagandose depois nas extremidades superiores, assim como no dorso, nuca, músculos abdominaes, aos intestinos e ao peito, suppressão das secreções da urina, da saliva e da bilis, cahida rápida das forças até completa prostração.[...] ao terceiro e ultimo período [...] Insensibilidade geral, suspensão da respiração, pulso lento, fraco, pequeno, intermitente, ou ausência delle, face decomposta, cadaverosa, lábios azulados, olhos encovados, vista fixa, frio de mármore, suor viscoso e frio de todo o corpo, voz rouca e fraquíssima, e em fim a morte sobrevem ao mero de tremores convulsivos. ${ }^{19}$

Embora o conhecimento sobre as causas, as formas de transmissão e de eficazes terapêuticas no combate à cólera, não fosse eficazes para deter 0 avanço da epidemia e, consequentemente, impedir o grande número de mortos e doentes, os médicos indicavam as mais variadas prescrições, buscando orientar a população e as autoridades a se prevenir e combater os males epidêmicos.

A Igreja e a população, diferentemente dos médicos, acreditavam na teoria divina da epidemia. Deus teria enviado a epidemia motivado pelos pecados cometidos pelos homens. Segundo David, o arcebispo da Bahia, Dom Romualdo Antonio de Seixas, dizia que reconhecia a "mão de Deus" na epidemia de cólera: "Para ele a divindade estaria manipulando a doença de maneira tão extraordinária que dificultava a descoberta de suas causas, de sua natureza e da sua identificação pela ciência médica." ${ }^{20}$ Para esse religioso, os pecados variados, como desacatos, usura, profanações, fraude, 
22

DINIZ, Ariosvaldo Silva. Cólera, representações de uma angústia coletiva: a doença e o imaginário social no Brasil do século XIX. 1997. 507 f. Tese (Doutorado em História). Programa de PósGraduação do Instituto de Filosofia e Ciências Humanas da Universidade Estadual de Campinas, Campinas/SP, 1997.

23

BELTRÃO, Jane Felipe. Op. Cit. p. 270.

RODRIGUES, Cláudia. Lugares dos mortos na cidade dos vivos: tradições e transformações fúnebres no Rio de Janeiro. Rio de Janeiro: Secretaria Municipal de Cultura, Departamento Geral de Documentação e Informação Cultural, Divisão de Editoração, 1997. p. 46

25

DELUMEAU, Jean. História do medo no Ocidente (1300-1800): uma cidade sitiada. São Paulo: Companhia das Letras, 2009. p. 146. calúnia e a violência, seriam os motivadores da ira divina contra a humanidade, "[...] era a vingança de Deus contra os pecados humanos."21

Em Pernambuco, segundo Ariosvaldo da Silva Diniz, Igreja e população afirmavam que a cólera seria "[...] uma flecha mandada por Deus, sobre a cidade da desordem, surpreendendo-a em meio aos seus prazeres e ceifando, de preferência, os indivíduos pecadores que se entregavam aos excessos das paixões e dos gozos brutais." 22

Analisando a ocorrência do surto de cólera na Província do Pará, Beltrão encontrou em jornais referências à doença como castigo divino. Como se acreditava que a realização de cultos, missas, procissões e vigílias daria fim à epidemia, esses rituais ocorriam com frequência. De acordo com a mesma autora, diversos periódicos locais conclamavam a população para a prática de ofícios religiosos, objetivando "[...] aplacar a ira dos céus e diminuir a devastação produzida pela epidemia [...]."23

A forma assustadora como a cólera se fez presente fez com que a Igreja divulgasse a ideia de que, como a doença era resultado dos pecados humanos, bastava que se pedisse perdão e os pecados seriam perdoados pela vontade magnânima da graça divina. Para tanto, era preciso rezar missas e orações, fazer penitências, flagelação, procissões, o que passou a ser seguido à risca pelos moradores de Vitória, capital da província, e certamente por todas as localidades provinciais, assim como foi comum em outras regiões do Brasil, como Sergipe, Maranhão, Pará, Bahia, Pernambuco, Rio Grande do Sul e Rio de Janeiro.

Reportando-se à questão da realização de procissões, como uma das formas de penitência para se conseguir purgar os pecados, Cláudia Rodrigues diz que elas se constituiam em súplicas, quando os moradores de uma dada localidade, indistintamente, não importando a que estrato social pertencesse, participavam do ato litúrgico, durante o qual oravam, cantavam e se arrependiam e gemiam, na expectativa de que Deus abrandasse a sua fúria, ouvisse suas lamentações e, dessa forma, afugentasse o surto epidêmico. Para tal intento, era "[...] necessário o máximo de círios, luzes, lamentos dos flagelantes e de preces ininterruptas." ${ }^{24}$

Se a doença atingia a todos sem distinção, todos deveriam pedir clemência em conjunto, pois só de forma coletiva podiam ser atendidos. Segundo Delumeau, "[...] as iniciativas individuais não bastavam [...] sentia-se a necessidade de implorações e de penitências públicas cuja unanimidade e 0 aspecto [...] quantitativo poderiam talvez impressionar o Altíssimo." ${ }^{.25}$

Assim as instituições religiosas, irmandades e população organizavam atos para a exortação da piedade divina, para livrar-se do flagelo reinante. As autoridades religiosas pregavam que tais atos litúrgicos possibilitariam que a população pudesse renovar seus laços com Deus, limpando suas consciências.

Nesse sentido, procissões, missas e rezas eram noticiadas fazendo chegar a informação a toda a população de uma localidade e até de áreas adjacentes. Inclusive ali foi utilizada para esse fim.

Embora a cólera só tivesse chegado à Província do Espírito Santo em final de novembro de 1855, em outubro, encontramos um anúncio de jornal relatando sobre a realização de uma procissão, na qual os moradores da Capital da província pediram à Providência Divina que os livrassem de tão terrivel mal. ${ }^{26}$ No mesmo jornal, divulgou-se ainda que, na madrugada de 6 de outubro, na Igreja da Misericórdia, cantou-se uma missa em homenagem a São Sebastião, pedindo a esse santo, protetor dos doentes, que os livrassem da peste. 
27

Idem, f. 3, 21/nov./1855.

28

Idem, f. 3, 07/nov./1855.

Da mesma forma, às vésperas de uma das datas possíveis de o primeiro caso da epidemia de cólera surgir no Espírito Santo, divulgou-se que, no dia 25 de novembro, no Convento de Nossa Senhora da Penha, seria celebrada uma missa cantada e, dessa forma, todos os fiéis e devotos da Virgem Santíssima eram convidados para esse ato cristão. Além dessa missa, foi noticiado, ainda, que no domingo, na quarta, quinta e sexta-feira seguinte a essa missa, aconteceriam, na Matriz da Vila do Espírito Santo (Vila Velha), preces. Culminando o evento, seria realizada uma procissão com as imagens de Nossa Senhora do Rosário e do Cristo Crucificado. ${ }^{27}$

0 anúncio a seguir corrobora a ideia da possibilidade de que as súplicas, rezas, missas, procissões e penitências pudessem aplacar a ira divina pela redenção dos pecados:

\begin{abstract}
As supplicas, e as preces tem sido em todos os tempos meio mais efficaz de aplacar a cólera divina, quando o senhor tem fulminado sobre as suas creaturas os raios da sua justa vingança; e quando estas são acompanhadas de uma verdadeira penitencia, cae inffalivelmente do CEO, em beneficio dos humanos, a torrente das divinas misericórdias: assim o prometteo Deus ao Salomão [...]. Sim, forão as supplicas de Moyses, e a penitencia dos israelitas, que aplacarão a cólera divina [...]. ${ }^{28}$
\end{abstract}

Como a epidemia de cólera no ano de 1856 ainda estava muito forte, no mês de abril, realizou-se uma procissão na qual os moradores imploraram a misericórdia divina para que aliviasse a Capital da província dos males que estava sofrendo:

Assistimos a esse acto de humilde devoção. Sublime era de ver-se a contricção, o recolhimento dos fiéis. Todas as classes da sociedade sahião em piedosa romaria, levados dos mesmos princípios impressionados da mesma ideia. Descalços, silenciosos, entregues a uma religiosa contemplação, seguirão por todas as ruas da cidade, os grandes, e os pequenos, os ricos e os pobres, os potentados e os humildes. Nunca vimos preces tão elevadas e verdadeiras supplicas.

Os rituais religiosos nos quais se pedia clemência ao Altíssimo não eram somente organizados pelas irmandades e população. Também membros da Igreja conclamavam o povo a participar desses atos, como fez o bispo de Vitória, convocando os paroquianos a pedirem clemência aos Céus para que o flagelo da cólera não continuasse a persistir:

E tempo de nos prostarmos a face dos altares, e com a força das nossas almas, contritos e humilhados, supplicarmos a Deos se digne, em sua misericórdia de afastar do meio de nos o flagello da peste que nos ameaça. A epidemia que tem ferido a tantos dos nossos irmãos em algumas provincias do Norte parece querer invadir esta diocese. ${ }^{29}$

Idem, f. 3, 03/out/1855.

Talvez em razão da intensidade do surto, a população realizava atos religiosos com pompa maior, transformando-se numa espetacularização, quem sabe na expectativa de impressionar a divindade para que tivesse compaixão do seu sofrimento, como o descrito a seguir:

Hontem chegou a esta cidade [Vitória] o Menino de Nossa Senhora da Penha. Veio acompanhado pelo Reverendo Guardião do Convento da Penha Frei João Nepumoceno Valladares, grande numero de canoas e botes fazião o cortejo: ao chegar ao Penedo, replicou o Rozario, e embandeiraão-se as embarcações sustas no porto; ao chegar ao Caes Grande muitos foguetes subirão ao ar: dahi seguiu para a Igreja do Convento de São Francisco acompanhado por um grande numero de 
A população da Província do Espírito Santo, na época em que aparece a epidemia de cólera, era de pouco mais de 49.000 habitantes, o que perfaz uma média de 3,5\% de mortos. Embora o número absoluto de mortes pareça pequeno, os impactos na economia, por exemplo, foram muito significativos, em função da queda da produção agrícola, por exemplo. Sobre o número de mortos na provincia, recomendamos a leitura do já citado relatório do presidente provincial José Maurício Fernandes Pereira de Barros.

DAEMON, Basilio Carvalho. Província do Espírito Santo: sua descoberta, história cronológica, sinopse e estatística. 2. ed. Vitória: Secretaria de Estado da Cultura, Arquivo Público Estadual do Espírito Santo, 2010.

33

Relatório apresentado pelo presidente $d a$ Província do Espírito Santo, José Mauricio Fernandes Pereira de Barros, que dirigiu a abertura da Assembleia Legislativa da mesma província, no dia 23 de maio de 1856. Victoria: Typographia Capitaniense de P. A d'Azeredo, 1856.

34

APE/ES. Fundo Governadoria, Série 383, Livro 202. Correspondência dos membros da Comissão Sanitária de Guarapari ao vice-presidente da Província do Espírito Santo, datada de 2 de janeiro de 1856.

35

APE/ES. Fundo Governadoria, Série 383. Livro 202. Correspondência da Secretaria de Polícia da Província do Espírito Santo ao vice-presidente provincial, datada de $1^{\circ}$ de fevereiro de 1856.

36

Correio da Victoria, 10 de novembro de 1855. f. 3 . pessoas. Consta-nos que hoje deve seguir para a Villa da Serra depois de visitar as enfermarias do Convento de São Francisco e da Capichaba.

Faremos votos que os Serranos sejão preservados do mal, e attendidos em suas supplicas. ${ }^{30}$

\section{A cólera chega ao Espírito Santo}

A epidemia de cólera que se manifesta na Província do Espírito Santo, em novembro de 1855, rapidamente se espalha por diferentes localidades, ceifando inúmeras vítimas, levando pânico e desespero por onde passava.

A falta de estrutura para atender às necessidades de um surto que ao final matou mais de 1.700 pessoas nos dá bem ideia dos impactos sofridos na província e da magnitude do pavor que essa epidemia provocou no seio da população. ${ }^{31}$

0 mapa a seguir nos mostra as localidades da Província do Espírito Santo onde a epidemia de cólera se fez presente. Como se pode verificar, a cólera circulou de norte a sul, entretanto foi nas regiões litorâneas, preferencialmente, que a epidemia se manifestou, o que reforça a ideia de que era por via marítima e fluvial que essa doença acabava chegando às diferentes localidades. A cólera se fez presente nas áreas litorâneas, no Norte: São Mateus, Barra de São Mateus, Santa Cruz; no sul: Piúma, Guarapari, Itapemirim, Benevente (Anchieta); e na área Central: Vitória, Espírito Santo (Vila Velha) e Nova Almeida. Nas localidades da Serra (sede), Carapina, Queimado, Mangarai, Cariacica e Viana, que não eram litorâneas, provavelmente a cólera chegou por via fluvial, graças ao comércio interno.

Com o surto epidêmico de cólera atacando diversas províncias do Brasil, já tendo atingido a província vizinha do Rio de Janeiro, uma das preocupações do Governo Provincial era como atender a toda a população, caso 0 surto aqui chegasse, em face ao pequeno número de médicos aqui existentes.

Em 1855, quando apareceu a epidemia de cólera, havia, na Província do Espírito Santo, dois médicos e dois boticários, para uma população de 49. 092 habitantes. $^{32}$

Diz o presidente da província, em 1856, que, tão logo tomou conhecimento da epidemia de cólera que reinava na Corte e no Rio de Janeiro, especialmente em Campos, cidade vizinha ao Espírito Santo, reuniu os profissionais da saúde existentes na Capital, com o objetivo de traçar medidas de combate, caso essa doença chegasse à província. Como não tinha orçamento para despesas dessa ordem, mandou, por responsabilidade própria, abrir crédito de três contos de réis, que foi distribuido pela Capital e localidades mais populosas. Ao Governo Imperial solicitou médicos e medicamentos, no que foi atendido, pois vieram quatro médicos e dois acadêmicos, trazendo remédios. ${ }^{33}$

Em Guarapari, a cólera chegou em dezembro. No final desse mesmo mês, sua intensidade diminuiu, mas, em janeiro, recrudesceu. Morreram 40 pessoas, cinco delas de ataque fulminante. ${ }^{34} \mathrm{Em}$ fevereiro, a situação piorou e o vice-presidente da província é informado de que a localidade precisava ser socorrida por estar em situação deplorável. Nesse sentido, o acadêmico que estava atendendo aos doentes pedia que fossem enviados medicamentos. ${ }^{35}$

Ao saber de dois casos suspeitos de cólera que haviam se manifestado na vila de Benevente, foi mandado para lá o médico Manoel Pinto da Motta, para que este pudesse se certificar da veracidade da doença, o que não foi confirmado. ${ }^{36}$

$\mathrm{Se}$, num primeiro momento, os casos não foram confirmados, no final desse mesmo mês, a cólera chega a Benevente e de lá se dirige para Guara- 
37

APE/ES. Fundo Governadoria. Série 383. Livro 202. Correspondência do médico de Guarapari Antonio Nascimento e Silva ao vice-presidente da Província do Espírito Santo, datada de 25 de dezembro de 1855.

38

APE/ES. Fundo Governadoria. Série 383. Livro 202. Correspondência do subdelegado de polícia de Itapemirim ao chefe de Polícia da Província do Espírito Santo, datada de 20 de novembro de 1855

39

Correio da Victoria, f. 3, 21/nov./1855.

40

Idem. f. 4, 12/dez./1855.

41

Idem, f. 4, 21/nov./1855.

42

APE/ES. Fundo Governadoria. Série 383. Livro 202. Correspondência do médico Antonio Nascimento e Silva ao vice-presidente $d a$ província, datada de $1^{\circ}$ de dezembro de 1855. pari, o que levou o Governo Provincial a deslocar para lá, a fim de socorrer os doentes, o médico Antonio Nascimento e Silva. Este, lá chegando diz que a situação era preocupante, pois a epidemia grassava com sintomas graves "[...] e em geral com caráter rebelde, regulando diariamente de três a quatro o numero de doentes cahidos." ${ }^{37}$

Depois de Guarapari o governo provincial toma conhecimento de que a epidemia havia chegado a Itapemirim, pois, preocupado com a situação naquela localidade, o subdelegado pediu que fosse enviado um médico e medicamentos que deveriam ser pagos com recurso do cofre Nacional, visto que a Câmara Municipal não dispunha de recursos para tanto..$^{38}$

Ainda no mês de novembro, a epidemia chegou à localidade de Itabapoana. 0 jornal Correio da Victoria relatou a correspondência do juiz de Paz dessa localidade para o presidente da província, informando que algumas pessoas ficaram doentes de cólera, mas que nenhuma chegou a óbito. Diante dessa situação, foi sugerido que o médico se dirigisse à localidade de Rio Preto, distrito de Itabapoana, por lá ter surgido um foco da epidemia onde já haviam morrido 11 pessoas. ${ }^{39}$

Pelo jornal Correio da Victoria, do dia 12 de dezembro de 1855, sabe-se que a epidemia havia chegado ao município de Viana. 0 anúncio relatava a preocupação de todos os moradores daquela localidade, por não existirem médicos, medicamentos ou pessoas que pudessem cuidar dos doentes. ${ }^{40}$

Outra localidade atingida pela cólera foi Piúma. Tão logo o Governo Provincial tomou conhecimento da chegada da epidemia de cólera naquele município, designou que o médico Manoel Gomes Bittencourt, que estava em Itabapoana, se dirigisse para Piúma, tendo este partido de madrugada, com o propósito de envidar "[...] todos os meos esforços em bem da humanidade aflicta." Bittencourt encontrou em Piúma um quadro bem diferente do que vivenciou em Itabapoana. Em frente à gravidade da situação, solicitou ao governo provincial que fosse enviada com urgência

\footnotetext{
Uma ambulância bem sortida, visto não me terem vindo todos os medicamentos que mandei buscar na cidade de Campos, e não haverem ainda chegado os que encommendei para o Rio de Janeiro, mormente experimentando-se a galba de algumas drogas na pharmacia desta Villa. ${ }^{41}$
}

Outra localidade na qual a epidemia apareceu foi no municipio do Espírito Santo (Vila Velha), onde a cólera se manifestou nos distritos de Ponta da Fruta e Barra do Jucu. 0 Governo Provincial designou que o médico Antonio Nascimento e Silva para lá se dirigisse. Ao chegar a essas localidades, o médico diz que a situação não era tão grave, pois só encontrou dois doentes com suspeita de cólera, apesar de um deles estar moribundo. Os demais casos não eram tão graves, pois a suspeita da epidemia de cólera não se confirmara. Os moradores tinham contraído em verdade a colerina que, apesar de ter sintomas semelhantes aos da cólera, era uma doença menos grave. ${ }^{42}$

Depois de ter percorrido Guarapari, Benevente, Piúma e Itabapoana, a cólera se dirige para Itapemirim. Só na vila principal desse município morreram 11 pessoas tão logo apareceu a epidemia. Na fazenda Muqui, de propriedade do vice-presidente da província, o Barão de Itapemirim, faleceram 40 escravos. A epidemia estava tão avassaladora nessa localidade que - Governo Provincial enviou cinco médicos e grande quantidade de medicamentos. Talvez a quantidade de médicos e medicamentos encaminhados 
43

Correio da Victoria, 19 de dezembro de 1855. f. 3.

44

APE/ES. Fundo Governadoria. Série 383. Livro 202. Correspondência do médico de Itapemirim ao vice-presidente da Província do Espírito Santo, datada de 30 de novembro de 1855.

45

APE/ES. Fundo Governadoria. Série 383. Livro 202. Relatório do médico comissionado Antonio Nascimento e Silva ao vice-presidente da Província, datado de 18 de janeiro de 1856.

46

Correio da Victoria, f. 4, 09/jan./1856.

47

APE/ES. Fundo Governadoria. Série 383. Livro 202. Correspondência da Secretaria de Polícia da Provincia do Espírito ao vice-presidente provincial, datada de 17 de janeiro de 1856. possa ser explicada pelo grande número de mortos ou ainda pelo fato de as fazendas do vice-presidente estarem sendo consumidas pelo flagelo. É claro que o jornal Correio da Victoria, por contar com anúncios oficiais, fez questão de fazer alusão na coluna Noticias Diversas anunciando a benevolência do Barão: "[...] tem-se tornado digno de nossa gratidão pelo zelo que tem demonstrado em bem da humanidade aflicta desta infeliz Villa." ${ }^{43}$

Ao chegar ao sul da província, a cólera se desenvolveu de forma avassaladora. Os médicos para lá deslocados constataram que não havia condições de deter o avanço do flagelo, "[...] porquanto, desde o dia 12 ou 13 [novembro] seus habitantes luctão com um terrivel inimigo da vida, que já algumas têm ceifado, e parecendo querer espalhar-se por todo o município," o que acabou acontecendo, pois a epidemia se fez presente em alguns vilarejos e fazendas do município. ${ }^{44}$

0 relato dramático do médico comissionado Antonio Nascimento e Silva ao presidente da província sobre a situação em Itapemirim nos dá bem a noção da gravidade vivida:

0 estado da Villa de Itapemirim no dia 10 de dezembro em que lá cheguei, era o mais desgraçado! Os cadáveres jazião por muitas horas insepultos, a epidemia lavrava com grande intensidade em toda a Villa. Havia uma enfermaria, que recebia os enfermos, porem sua má localidade, e o acanhamento da casa, obrigou-me a officiar a V. Ex. de prompto oseu sobrado na praça, e por essa occasião enviou mais dinheiro, medicamentos e colxas. No sobrado de V. Ex, foi creada a enfermaria, com que concordarão os directores da outra, que não attingiu os fins desejados, concluindo eu d'ahi, eu estavão de accordo a aceitar os auxílios do governo, tanto mais que estabelecida esta nova enfermaria. Mandando eu medicamentos e colxas para o hospital não acceitarão; - entendi-me à respeito com o presidente da commissão sanitária, o padre José Fellipe Pinheiro, que convocando uma reunião em casa de M.J d'Araújo Machado, tivemos de ouvir ahi a declaração, de guinada por ora querião do governo, concluindo depois de differentes reflexões de pessoas presentes, que acceitarião tudo, quando se acabasse o dinheiro que tinhão; em caixa. He preciso notar que nessa occasião já a em caixa. He preciso notar que nessa occasião já a enfermaria estava na casa de V. Ex, com o respectivo medico e um servente pago pela commissão sanitária. Os medicamentos depositei parte em casa do Dr. Cunha, e parte à minha disposição, notando-se que o Dr. Antonio Pinto da Cunha, commissionado pelo governo, não só estava a testa d'aquella enfermaria, como continuava a prestar aos enfermos medicamentos que irão do governo. As quantias mandadas por V. Ex. pôr a disposição da Comissão foi de 1:1000\$rs, que regularmente iaô sendo distribuídas pelos pobres.

Das ofertas particulares nada sei, a excepção de seis escravos que o tenente-coronel Heliodoropoz à minha disposição, um garrote e mais seis arrobas de assucar, que forão distribuídos pelos pobres, e do coronel Gomes que me prometteo mandar seos escravos fazer a mudança do cemitério. São os donatvos que durante a minha estada nella recebi.

Actualmente os doentes do hospital são os escravos do fazendeiro Póvoa, que recebem alli tractamento mediante a quantia de 1:500 rs diários, segundo me consta. ${ }^{45}$

Só em janeiro a epidemia começa a declinar na cidade de Itapemirim, permanecendo somente no interior e nos arredores da vila. ${ }^{46}$

Próximo a Itapemirim, na localidade de Itapoca, a epidemia também se fez presente, tendo sido para lá enviados medicamentos. A gravidade da doença não foi excessiva, já que o número de mortos não passou de cinco pessoas. ${ }^{47}$

Foi na Capital da província que morreu um maior contingente de pessoas. 0 padre Antunes Siqueira, que vivenciou a passagem da cólera na cidade, fez o seguinte relato: 
SIQUEIRA, Francisco Antunes. Memórias do passado: a Vitória de meio século. Vitória: Flor\&Cultura, 1999. p. 112-113.

49

APE/ES. Fundo Governadoria. Série 383. Livro 202. Correspondência do médico Luiz Gonzaga d'Araujo Bastos ao vice-presidente da Província do Espírito Santo, datada de 16 de dezembro de 1855. 50

APE/ES. Fundo Governadoria. Série 383. Livro 202. Correspondência do membro da Comissão Sanitária de Itapemirim ao vice-presidente da província, datada de 26 de dezembro de 1855.

51

Correio da Victoria, 16/abr./1856.

52

APE/ES. Fundo Governadoria. Série 383. Livro 202. Correspondência da Secretaria de Polícia ao presidente da Província do Espirito Santo, datada de 22 de abril de 1856.

53

Correio da Victoria, f. 4, 16/fev./1856

54

Idem. f. 3, 09/jan./1856.

55

APE/ES. Fundo Governadoria. Série 383. Livro 202. Correspondência do subdelegado de polícia da Serra, João da Costa Silva Borges, ao chefe de polícia da Província do Espírito Santo, datada de 25 de janeiro de 1856.
Em 1856 passou a província por uma dura provança!. 0 cólera-morbo, hospede asiático, emigrou para o nosso pais, sem previa desinfecção. Sucumbiu após três dias, aquele estafeta na rua da Lapa [Atual Thieres Veloso] e desde então disseminou-se o mal de um modo assustador! Era tão grande o número dos doentes que não o podiam contar o hospital da santa Casa, as enfermarias da Capixaba, do Carmo e São Francisco! Consternado, abatido, o povo tocava o auge da desesperação! As famílias aterradas fugiam para o interior e outras mais resolutas buscavam os templos juncavam junto aos altares! Ao passarem 8, 12, 16 e até 25 cadáveres carregados pela galés, as familias gritavam das janelas: - Misericórdia, meu Deus, socorrei o vosso povo!!!

Valas externas se abriam junto ao convento, naquela encosta onde se achavam os cemitérios de são Benedito, Sacramento e outros, e ali se amontoavam as vítimas desse mal terrivel. ${ }^{48}$

Confirmando o que outros estudos em diferentes regiões do Brasil apontaram, no Espírito Santo, também foram os mais pobres a maioria das vítimas da cólera. Na capital da província, Vitória, o médico Luiz Gonzaga d'Araujo Bastos, ao percorrer as diferentes ruas da cidade, diz ter ficado preocupado com o foco de epidemia no Beco do Estanque, onde habitava a população mais pobre. ${ }^{49} \mathrm{Um}$ membro da Comissão Sanitária de Itapemirim, Antonio Pinto da Cunha, diz que, em Itapemirim, embora a epidemia tivesse surgido às margens do rio, era nas fazendas que ocorria o maior número de mortos e, entre os mortos, os escravos era maioria. ${ }^{50}$

Em Nova Almeida, inicialmente a cólera não apareceu. No entanto, um surto da doença chamada câmaras de sangue causou grandes estragos na população, mas felizmente todos os doentes se restabeleceram com 0 tratamento aplicado. Se, num primeiro momento, a população ficou livre da cólera, o surto logo não tarda a aparecer. Segundo o jornal Correio da Victoria, seu efeito foi devastador: "[...] os índios estavam morrendo as dúzias" ${ }^{11}$ e, para complicar mais a situação, faltavam médicos, medicamentos e enfermarias para acolher tantos doentes.

Em Santa Cruz, as primeiras notícias que se têm da cólera foi com a morte do soldado Antonio Pedro. Nessa localidade, as mortes estavam ocorrendo mais na região interiorana, como Caieiras Velhas, local onde moravam os habitantes remanescentes da aldeia dos tupiniquins que estavam morrendo em grande quantidade. ${ }^{52}$

Também havia notícias da presença da cólera em Jacaraipe, levando à morte várias pessoas. 0 governo enviou para lá medicamentos a serem distribuídos para a população pobre. De acordo com o Correio da Victoria, os moradores dessa localidade estavam "[...] sendo disimados cruelmente pelo flagello. Consta-nos que tem fallecido mais de 20 pessoas! Para a pequena população que ali existe, o numero he extraordinário." 53

$\mathrm{Na}$ Serra, a cólera não apareceu inicialmente com intensidade, ocorrendo somente casos esporádicos..$^{54} \mathrm{Em}$ janeiro, ela se intensifica, levando 0 subdelegado de polícia a dizer que a doença "[...] invadiu esta Villa preocupando com caracter assustador." ${ }^{15}$ Declara ainda o mesmo subdelegado que, para conseguir atender a todos os doentes, oficiou ao acadêmico Francisco Gomes de Azambuja, que já estava assistindo os doentes, que fixasse residência na vila da Serra, a fim de melhor tratar os enfermos. A preocupação do subdelegado deve ter crescido ainda mais, quando soube que a sua solicitação não poderia ser atendida, em razão de o Governo Provincial ter deslocado o referido médico para a localidade de Queimado, onde também estava ocorrendo surto da doença. Relata por fim o subde- 
56

APE/ES. Fundo Governadoria. Série 383. Livro 202. Correspondência do subdelegado de polícia da Serra, João da Costa Silva Borges, ao chefe de polícia da Província do Espírito Santo, datada de 25 de janeiro de 1856

57

Correio da Victoria, f. 3, 30/jan./1856.

Ibidem.

59

APE/ES. Fundo Governadoria. Série 383. Livro 202. Correspondência do delegado de polícia de São Mateus ao chefe de polícia da Província do Espírito Santo, datada de $1^{\circ}$ de janeiro de 1856.

60

APE/ES. Fundo Governadoria. Série 383. Livro 202. Correspondência do delegado de polícia de São Mateus, ao chefe de polícia da Província do Espírito Santo, datada de 26 de abril de 1856.

61

APE/ES. Fundo Governadoria. Série 383. Livro 202. Correspondência do subdelegado de Mangarai ao chefe de polícia da Província do Espírito Santo, datada de 2 de janeiro de 1856.

APE/ES. Fundo Governadoria. Série 383. Livro 202. Correspondência do presidente da Comissão Sanitária de Mangaraí, Ladislau Ferreira, ao vicepresidente da Província do Espirito Santo, datada de 7 de fevereiro de 1856. legado que tal notícia muito o entristeceu, pois, no seu entender, a cidade da Serra estava "[...] em uma completa mizeria, não [tinha] remédios, não [tinha] hospital, não [tinha] cemitério, os corpos de certo serão enterrados na igreja, como já aconteceu hontem." ${ }^{16}$

No final do mês de janeiro, a epidemia ainda estava forte na Serra, o que levou alguns moradores a enviar cartas ao jornal Correio da Victoria, que publicou, na coluna Notícias Diversas, o que lá estava acontecendo. Pelas notícias, fica-se sabendo que o povo estava bastante amedrontado e pedia a presença de médicos e também que fossem enviados medicamentos:

Estamos a braços com a epidemia. A primeira victima foi uma escrava de uma pobre viúva, a qual apenas durou 24 horas [após contrair a cólera]; se continuar assim, teremos aqui grande mortandade, não so pela muita pobreza que há, como por absoluta falta de recursos. Não temos medico, nem medicamentos, nem enfermaria, e nem se quer um curioso que tratem os que forem atacados [...]. 0 terror he grande, e o desanimo quase geral, pois todos conhecem que se a epidemia estender-se pelas fazendas, a villa da Serra, fica aniquilada para sempre. ${ }^{57}$

Interessante, no anúncio citado acima, é que a população incorporava a presença de "curiosos" como possivel para socorrê-la à frente das moléstias que a afligiam.

Em Carapina, distrito da Serra, têm-se notícias da presença da cólera desde janeiro de 1856, aumentando sua intensidade devido às torrenciais chuvas que caíram. As planícies que cercavam a freguesia ficaram inundadas. Tão logo a epidemia se manifestou, nove pessoas morreram, não tendo havido tempo nem para a aplicação de medicamento. ${ }^{58}$

Em São Mateus, até o mês de dezembro, não se tem notícia da presença da cólera, mas, em janeiro, a epidemia chega com força nessa localidade e em Barra de São Mateus. Foi necessário o Governo Provincial enviar para essas localidades médico e medicamentos. ${ }^{59}$ Nesses locais, além da cólera, outras enfermidades se faziam presentes, como as febres intermitentes, que apresentavam alguns sintomas semelhantes ao da cólera, como vômitos e diarreia, sempre no período após a ocorrência das cheias do rio São Mateus. Segundo o delegado de polícia, essa doença apresentava "[...] caracteres bem espantozos e segundo me consta fazendeiros há, que tem vindo para a Cidade com suas familias em procura de soccorros médicos." ${ }^{60}$

$\mathrm{Se}$, em janeiro, o surto de cólera apresentava sinais de abrandamento em algumas localidades, em outras ele começava a aparecer com toda a força. Foi o caso de Mangaraí. De acordo com o subdelegado, em Água da Costa, vilarejo que pertencia a Mangaraí, especificamente na fazenda Regência, ocorreram casos da doença. Alguns enfermos faleceram em poucas horas, por isso o subdelegado diz que o terror estava se apoderando dos moradores. Alertava que, se o mal continuasse, o número de mortos seria imenso pela inexistência de recursos..$^{61}$ Outras localidades, como São Miguel, Morundum, Guararemas, que faziam parte da abrangência da Comissão Sanitária de Mangaraí, apresentavam casos fatais da doença. Relata a Comissão de Mangari alguns casos que considerava preocupantes, como o fato de os escravos não procurarem a Comissão para que Ihes aplicassem remédios, além de estar ocorrendo, naquele momento, fortes chuvas, impedindo-os de visitar todos os enfermos. ${ }^{62}$ É preciso que se entenda que, geograficamente, essas localidades não eram tão distantes uma das outras, o que dificultava 0 acesso era a falta de estradas e pontes, o que, em época de chuvas, tornava intransitáveis os caminhos e picadas que as interligavam. 
63

APE/ES. Fundo Governadoria. Série 383. Livro 202. Correspondência do médico de Guarapari ao vice-presidente da Província do Espírito Santo, datada de 20 de dezembro de 1855.

64

APE/ES. Fundo Governadoria. Série 383. Livro 202. Correspondência dos membros da Comissão Sanitária de Itapemirim ao vice-presidente da Província do Espirito Santo, datada de 30 de novembro de 1855.

65

APE/ES. Fundo Governadoria. Série 383. Livro 202. Correspondência do médico comissionado do governo imperial ao vice-presidente $d a$ Província do Espírito Santo, datada de 18 de janeiro de 1856.
Ações do Estado no combate às epidemias

Atender toda a população afligida pela cólera não foi uma tarefa fácil para o governo da Província do Espírito Santo. As necessidades eram grandes e os recursos disponiveis nem sempre suficientes. As distâncias geográficas, as dificuldades em superar os caminhos improvisados que interligavam uma localidade a outra, além da já comentada falta de médicos, medicamentos, hospitais e enfermarias, foram fatores que contribuiram na dificuldade em assistir a todos os enfermos.

Outras razões foram apontadas como dificultadoras à assistência aos enfermos. Para o médico José Joaquim Pereira Lima, a falta de pessoal habilitado para lidar com a cólera e a falta de medicamentos teriam sido os fatores mais importantes para a proliferação da doença e a dificuldade de atendimento aos enfermos. Para ele, ainda, a ignorância da população, que não seguia à risca as prescrições médicas, era também outro importante fator. Falando sobre a ignorância da população, um médico que estava atendendo aos doentes em Guarapari assim se reporta a esse problema. Diz tal médico que a população era "[...] estupida e embrutecida, que não podem comprehender como se possa viver tres a quatro dias sem comer, o que [determinava] à quebra do resguardo tão essencial a esta molestia, produzindo assim uma recahida dos enfermos." ${ }^{63}$ Não podemos esquecer que, para os médicos da época, a dieta e a ingestão de alguns alimentos seriam responsáveis pela proliferação dessa doença.

Da mesma forma pensavam os integrantes da Comissão Sanitária de Itapemirim, ao creditarem à ignorância do povo o problema da continuidade da epidemia e do excessivo número de mortes naquele município. Afirmavam que os moradores locais não ouviam as recomendações das autoridades e ainda relutavam em buscar socorro, só procurando atendimento, recorrendo ao médico, quando o seu estado de saúde era desesperador, quando "[...] todas as applicações são infrutíferas, e o doente [era] uma victima morta." 64

Os casos apontados buscam, portanto, isentar o Governo Provincial de responsabilidade pela ocorrência dos surtos epidêmicos e incorpora a ideia de que a população tinha todos os recursos para ser tratada, o que não era verdade. Aqui cabe porém uma explicação: embora nessa época a assistência à saúde fosse caritativa, não uma obrigação do Estado, não obstante o governo subsidiava essa caritatividade e, em casos como o aparecimento de uma epidemia, em que o número de doentes e mortos tomava proporções espetaculares, era natural que a população buscasse e exigisse uma participação do governo no socorro a população.

A desorganização da província em frente ao mal que deixava todos atônitos, as dificuldades no controle da máquina estatal para operacionalizar as ações ao combate à epidemia e os desmandos da máquina administrativa não eram levados em conta. Um médico comissionado, enviado pelo Governo Central para atender aos coléricos da Província do Espírito Santo, ao relatar que suas ordens não eram cumpridas, evidencia os desmandos administrativos. Esse médico, indignado, dizia que não era possivel "[...] que um medico que dirige uma enfermaria [estivesse] sugeito aos manejos de subalternos influenciando a quem quer que seja." 65

Em razão da falta de recursos financeiros e da falta de estrutura médico-hospitalar, o Governo Provincial tinha dificuldades em atender aos enfermos de surtos epidêmicos. Para suprir a falta de pessoal habilitado no atendimento aos doentes, o governo era obrigado a realizar improvisações, 
66

APE/ES. Fundo Governadoria. Série 383. Livro 202. Correspondência da Secretaria de Polícia ao vice-presidente da Província do Espírito Santo, datada de 5 de março de 1856.

67

APE/ES. Fundo Governadoria. Série 383. Livro 202. Correspondência de José Joaquim Pereira Lima, membro da Comissão Sanitária de Cariacica ao vice-presidente da Província do Espirito Santo, datada de 24 de janeiro de 1856.

68

APE/ES. Fundo Governadoria. Série 383. Livro 202. Correspondência do vice-presidente $d a$ Província do Espírito Santo ao vigário de Carapina datada de 28 de janeiro de 1856.

69

APE/ES. Fundo Governadoria. Série 383. Livro 202. Correspondência do professor de primeiras letras, Firmino de Almeida Silva, ao vicepresidente da Província do Espírito Santo, datada de 18 de janeiro de 1856.

70

APE/ES. Fundo Governadoria. Série 383. Livro 202. Correspondência do subdelegado de Polícia do distrito de Itapoca, Ricardo Pinto da Silva Queiroz, ao vice-presidente da Província do Espírito Santo, datada de 19 de janeiro de 1856.

APE/ES. Fundo Governadoria. Série 383. Livro 202. Correspondência da Secretaria de Polícia ao vice-presidente da Província do Espírito Santo, datada de 14 de janeiro de 1856.

72

APE/ES. Fundo Governadoria. Série 383. Livro 202. Correspondência do médico Manoel Pinto da Motta ao vice-presidente da Província do Espirito Santo, datada de 14 de janeiro de 1856.

APE/ES. Fundo Governadoria. Série 383. Livro 202. Correspondência do vice-presidente $d a$ Província do Espírito Santo à Câmara Municipal da Serra, datada de 7 de janeiro de 1856.

74

Correio da Victoria, 12/dez./ 1855. p. 3.

75

APE/ES. Fundo Governadoria. Série 383. Livro 202. Correspondência dos membros da Comissão Sanitária de Itapemirim ao vice-presidente da Província do Espírito Santo, datada de 30 de novembro de 1855 . como a feita em Guarapari, onde o subdelegado e "alguns curiosos" tiveram que aplicar medicamentos "aos enfermos que o requisitavão" em razão de o acadêmico Francisco de Souza Oliveira que ali atuava ter sido deslocado para a cidade de Vitória. ${ }^{6}$

Em Cariacica também se recorreu a moradores dessa localidade que passaram a ministrar os remédios que para lá foram enviados pelo Governo Provincial, seguindo "a receita de sua applicação." 67

Por não ter médico atuando em Carapina, o vice-presidente da província solicita à Comissão Sanitária de Vitória que entregue os medicamentos disponibilizados para aquela localidade ao "[...] padre para que este pudesse aplicá-los aos pobres." ${ }^{68} \mathrm{Na}$ Serra, o professor de primeiras letras, Firmino de Almeida da Silva, em face à inexistência de pessoal habilitado para tratar os doentes de cólera, passou a desempenhar simultaneamente as funções no magistério e no tratamento dos doentes. ${ }^{69}$

Nem sempre os recursos financeiros disponibilizados a atender aos doentes eram suficientes. 0 subdelegado de polícia de Itapoca pedia que fossem enviados mais medicamentos em razão do deplorável estado em que se encontravam os moradores daquele distrito..$^{70} 0$ inspetor de quarteirão da Barra do Jucu solicitava mais medicamentos porque acabaram os que para lá foram enviados. ${ }^{71}$ A solução encontrada foi as localidades se socorreram mutuamente com empréstimos feitos umas às outras.

Da mesma forma, houve improvisações no que concerne à falta de médicos para socorrer todos os pedidos que chegavam ao Governo Provincial. A solução foi fazer o deslocamento de médicos de uma localidade para outra. Sempre que uma área se mostrava em maior perigo pelo ataque da cólera, um médico era para lá desviado, o que acabava gerando muita insatisfação e reclamação. 0 médico Manoel Pinto da Motta informa que, após ter recebido a designação, deslocou-se de Vitória para a cidade de Itapemirim, para se juntar a outros médicos que lá já estavam trabalhando. ${ }^{72}$ A Câmara Municipal da Serra recebeu a informação de que o acadêmico Francisco Gomes de Azambuja Meirelles fora designado de Vitória para aquela localidade a fim de atender aos enfermos da cólera. ${ }^{73}$ Também o médico Antonio Francisco Fernandes foi removido de São Mateus para Vitória, em razão de que, em São Mateus, até aquela data, a cólera não havia se manifestado. ${ }^{74}$

Outra forma de socorrer a população era garantir alimento aos necessitados. A cólera afetava as pessoas que contraíam a doença, deixando-as prostradas por vários dias atingindo especialmente a população mais pobre. Estes, por dependerem do labor do dia a dia para garantir o seu sustento, em razão do seu estado de saúde, não conseguiam trabalhar, o que demandava que o Governo Provincial se responsabilizasse por sua alimentação. A Comissão Sanitária de Itapemirim informa ter recebido "[...] farinha, carne-seca, arroz e [...] dez mil réis" para serem distribuídos "[...] entre os indivíduos pobres e desvalidos." ${ }^{.75}$

Ações do Estado no socorro às vítimas dos surtos epidêmicos, buscando minimizar o seu sofrimento, faz-nos acreditar que esses surtos foram fundamentais para que políticas públicas para a saúde fizessem parte do planejamento dos governos que se sucediam. 0 perigo iminente de que um novo surto epidêmico pudesse chegar a qualquer momento foi determinante para que o Estado buscasse garantir assistência à população. 
PATTO, Maria Helena Souza. Teoremas e cataplasmas no Brasil monárquico: o caso da medicina social. Novos Estudos, São Paulo: CEBRAP, n. 44, mar./1996. p. 180-199.

77

REIS, João José. 0 cotidiano da morte no Brasil oitocentista. In: NOVAIS, Fernando A. (Org.). História da vida privada no Brasil. São Paulo: Companhia das Letras, 1997. Vol. 2. p. 96-141.

78

GONDRA, José. Artes de civilizar: medicina, higiene e educação escolar na corte imperial. Rio de Janeiro: EDUERJ, 2004. p. 188.

79

FIGUEIRED0, Betânia Gonçalves. As doenças dos escravos: um campo de estudos para a história das ciências da saúde. In: NASCIMENTO, Dilene Raimundo et al. (Org.). Uma história brasileira das doenças. Rio de Janeiro: Mauadx, 2006. Vol. 2. p. 252-273.

80

GONDRA, José. Op. Cit. p. 25

81

MADEL, T. Luz. A arte de curar versus a ciência das doenças: história social da homeopatia no Brasil. São Paulo: Dynamis Editorial, 1996.

82

Fala que o presidente da Província do Espirito Santo dirigiu à Assembleia Legislativa Provincial no dia $1^{\circ}$ de abril de 1840 . Rio de Janeiro: Typograpphia Nacional, 1849.

83

Correio da Victoria, f. 2, 06/fev./1856.
A vivência cotidiana com os surtos epidêmicos

Embora o número de médicos estivesse crescendo no País graças à criação de cursos de Medicina que foram implantados pós-chegada da família real portuguesa ao Brasil, em 1808, e a vacina tenha sido descoberta por Edward Jenner, o fato é que os conhecimentos médicos ainda eram muito precários, até porque, como diz Patto, ${ }^{76}$ "[...] o grosso da medicina era praticado por cirurgiões-barbeiros [...], barbeiros, boticários, aprendizes [...] curandeiros, entendidos, etc. [...]." Para essa autora, havia falta de pessoal qualificado, além, é claro, da falta de medicamentos e hospitais para atender à demanda. A carência existia inclusive em áreas onde havia curso superior de Medicina, como no Rio de Janeiro e na Bahia.

João José Reis ${ }^{77}$ afirma que a criação de cursos de Medicina e a ampliação do número de médicos não foram suficientes para dar conta dos problemas advindos com o surgimento de diversos tipos de surtos epidêmicos que se desenvolveram no século XIX, uma vez que, nesse período, 0 crescimento urbano e populacional, com concentração de pessoas em um mesmo espaço, passou a favorecer o aparecimento das epidemias. Como afirma José Gonçalves Gondra, ${ }^{78}$ a criação de cursos de Medicina e o maior quantitativo de médicos no mercado "[...] não significou na ruptura imediata e completa com as práticas de cura existente no seio da população [...]."

Estado e população agiram de forma diferenciada no que concerne a encontrar solução para enfrentar as epidemias. As práticas cotidianas de um povo "[...] trazem consigo uma determinada concepção de doença, corpo e medicamento [...], ${ }^{\text {"79 }}$ uma forma de interpretação que certamente diferia da dos médicos.

Os médicos, especialmente no pós-surgimento dos surtos epidêmicos, procuraram conquistar a autoridade que até então não tinham. Buscaram valorizar o seu saber, visando a uma legitimação que permitisse, a partir de então, "[...] dispor sobre saúde, doença, corpos, vida social e escolar [...]." ${ }^{180}$

Os médicos oficiais (alopatas) investiram pesadamente no combate ao conhecimento popular e até mesmo de outros profissionais da saúde, como os médicos homeopatas, impingindo-Ihes uma perseguição implacável, na busca de se firmarem como os únicos detentores do saber, o que obviamente não impediu que as práticas médicas populares e as homeopatas continuassem a existir. ${ }^{81}$

Prova cabal de que a população não abandonava as práticas médicas populares pode ser encontrada no relato do presidente da província no ano de 1840, ao afirmar que a população de São Mateus poderia facilmente curar-se das febres intermitentes que afligiam aquele povoado, se os doentes fossem tratados por médicos, mas eles preferiam recorrer a curandeiros, por confiarem nestes, e só procuravam os médicos depois do uso de remédios caseiros, quando o mal não tinha mais cura. ${ }^{82}$

0 jornal o Correio da Victoria, ao informar sobre o surgimento da cólera em Itapemirim, que já havia matado mais de 20 pessoas nesse município, diz que temia que a situação naquela localidade se agravasse ainda mais, não só por falta de médicos, mas principalmente porque a população teimava em buscar a cura com curandeiros. Sobre isso diz: "Com a falta de médicos que ali há, e com uma praga de curandeiros que tem surgido naquella pobre Villa, parece que em poucos dias ficara ella deserta." ${ }^{83}$

Dentre os remédios caseiros conhecidos e disseminados entre a população, encontramos larga referência ao uso do sumo do limão como antídoto para os males provocados por epidemias. 
Estando o cholera a fazer estragos nas villas dos Reis Magos e Santa Cruz, e conhecendo os bons resultados da applicação da calda de limão que tem feito milagres acconselho à esses povos esta applicação que todos podem fazer da maneira seguinte. Logo que a diarrehéa, dor na barriga, ou vômitos apparecer [...] tomar logo uma colher de sopa, de hora em hora [...]. Em quanto se applicão o limão, se não da caldo nem comida: se tiver secura, quando pedir água, se lhe dê limão com água, uma parte de limão, e quatro de água, se tiver vômito pertinases,se dê de meia em meia hora o limão e quando o mal for diminuindo, se vae espassando o remédio. [...] com esta applicação fácil e prompto, se tem curado muitos cholericos, e alguns em grande perigo, me parece nada haver melhor, quando applicado logo no principio da moléstia. ${ }^{84}$

Nesse dia, o mesmo jornal noticiou que os médicos homeopatas, na enfermaria constituida na Capital da província, estavam utilizando sumo de limão para a cura dos doentes de cólera, sob a alegação de que seu uso já estava disseminado e era do conhecimento de todos os benefícios que essa medicação fazia.

Em sua pesquisa sobre a ocorrência da cólera no Pará, Jane Felipe Beltrão afirma que, embora os médicos por princípio condenassem o saber dos profissionais de saúde popular, muitos deles se apropriaram desses conhecimentos, buscando revesti-los de uma roupagem científica.

Em relação ao uso do sumo de limão na cura da cólera, a mesma autora faz referência a essa prática, dizendo inclusive que essa terapêutica foi a mais largamente empregada. Assim como no Espírito Santo, "O tratamento consistia em oferecer ao enfermo sumo de limão as colheradas em pequenos intervalos de tempo ou em maiores intervalos de acordo com a gravidade do caso." 85

Além do sumo, muitos outros medicamentos eram indicados pelos profissionais populares da saúde no combate à cólera, conforme a imprensa registrou. 0 jornal Correio da Victoria publicou, em sua edição de 5 de dezembro de 1855, uma indicação popular de procedimentos para a cura da cólera.

\footnotetext{
Logo que apparecer os primeiros symptomas, deve-se tomar um escaldadapés, e qualquer sudorífico, usando-se internamente de uma solução de gomma arábica; isto é, de duas em duas horas uma chicara da dita solução com 4 gotas de láudano de Sydenham:- deve-se também usar de Clysteis de polvilho com 8 gotas de láudano, se continuar a ter frio o doente, será bom applicar um sinapismo na barriga de todo, tome-se então um purgante de óleo de rícino. Com este pequeno tractamento temos curado a muitos doentes, e um só temos perdido, apesar de não sermos médicos. ${ }^{86}$
}

Embora pudessem até utilizar os conhecimentos populares na busca da cura das doenças, o saber médico oficial os condenava de pronto, preceituando outro modus operandi para curar os enfermos da cólera, como alternativas para evitar a doença: limpeza e asseio das casas, dos quintais, das praças e fontes; retirada de entulhos e lixo encontrados nas praias; eliminação dos sepultamentos dentro das igrejas; inspeção da venda de alimentos; uso de fogueiras para purificar o ar e afastar os miasmas; uso do cloro e caiação das casas para desinfecção de ambientes.

\section{0 medo da cólera}

De todas as doenças epidêmicas que apareceram no século XIX, nenhuma causou mais pavor que a cólera. 0 não conhecimento de sua origem, 0 grande número de mortes que ela provocava, o desconhecimento sobre o que prescrever para que tal flagelo desaparecesse, tudo isso deixou as populações das localidades onde ela esteve presente atônitas e indefesas. 
87

BELTRÃO, Jane Felipe. Op. Cit. p. 266.

88

SIQUEIRA, Francisco Antunes. Op. Cit. p. 114.

Mas do que vitimar fatalmente os enfermos, a cólera causou grande impacto social. Morrer de cólera era "[...] considerado humilhante, pois os coléricos [perdiam] as suas caracteristicas humanas, [morriam] como se fossem bichos, bestas feras. ${ }^{187} \mathrm{~A}$ doença degradava os enfermos, deformando-os, deixando-os com fisionomia bestial. Diz o Padre Francisco Antunes Siqueira que os falecidos de cólera:

\begin{abstract}
[...] apresentavam um aspecto medonho! Olhos profundamente encovados: mãos e pés hirtos de um frio congelado; cútis toda contraída; queixos cerrados; abdômen e ventre completamente dessecados pela irritação dos intestinos; pescoço, pernas e braços contorcidos; enfim inteiramente desfigurados! Era horroroso! A última e mais fatal crise manifestava-se por uma algidez penetrante, rouquidão, desfalecimento e vômitos de um líquido transparente e gomoso. Seguia-se um estado comatoso, e dai a morte [...] ${ }^{88}$
\end{abstract}

\title{
Os impactos da passagem da cólera
}

0 temor e o pavor que a cólera provocava levaram a que comportamentos enraizados na sociedade fossem se modificando. 0 medo do contágio pela doença fez com que os enterros, os rituais fúnebres e a assistência aos enfermos fossem se modificando. Se, antes desse flagelo, a doença e a morte eram espaços de sociabilidade "[...] $]^{89}$ na qual as familias abriam suas portas [...]" para o envolvimento de todos, pós- epidemia, o doente e o defunto passaram a ser afastados do convívio com as pessoas. Rituais de sepultamentos chegaram a ser suprimidos, por medo de contágio da doença.

A multiplicação em escala assombrosa do número de enfermos e mortos foi determinante para que os cuidados com os doentes e os rituais de sepultamento sofressem modificações. 0 Correio da Victoria diz que, como se propagou a ideia de que o mal era contagioso, as vítimas da cólera começaram a ser abandonadas, ficando sem socorro algum.

\section{0 próprio vigário recusou-se a administrar-lhes os sacramentos, e prohibio até que fossem enterrados no cemitério da freguesia. Imitado este péssimo exemplo por alguns fazendeiros que tinhão cemitérios, forão os cadáveres sepultados nos campos..$^{90}$}

Correio da Victoria, f. 1, 03/nov./1855

91

Idem, f. 2, 05/dez./1855.
92

Idem, f. 2, 09/jan./1856.
0 medo da doença fazia com que fossem esquecidas obrigações de ofício. Não foi apenas no campo religioso que isso ocorreu. No mês de dezembro de 1855, o Correio da Victoria relatou também que, na vila de Itapemirim, o negociante Thimóteo de Toledo Leite e os médicos Ortiz e Lapa desapareceram com medo da cólera. ${ }^{91}$ Noticia, ainda, que fugiram também da vila o delegado e o juiz municipal e de órfãos.

Fugir de assistir os doentes de surtos epidêmicos, negligenciar a garantia dos rituais de enterramentos foram, sim, uma realidade na Província do Espírito Santo. Em 1856, o Correio da Victoria publicou, na coluna Publicações a Pedido, o seguinte registro:

\footnotetext{
Temos ouvido [...] queixas sobre a maneira porque se fazem os enterramentos [...]. Dizem-nos que os cadáveres são separados sem receberem as accomodações e mais officios que a nossa religião ensina em taes casos e será isso verdade? Parece-nos impossivel, porem infelizmente todos dizem que nem uma gota de água benta é lançada sobre o infeliz que morre [...]. pedimos uma providencia qualquer para que cesse esta falta de religião e de caridade[.... ${ }^{92}$
}

A solidariedade e o cuidado com as vítimas

0 medo, a fuga, a negligência em socorrer os doentes ou em garantir os rituais funerários não foi certamente a única realidade na província. Mesmo 
APE/ES. Fundo Governadoria. Série 383. Livro 202. Correspondência do médico Manoel Gomes Bittencourt ao vice-presidente da Província do Espírito Santo, datada de 19 de novembro de 1855

96

MERGÁR, Arion. A representação feminina nos autos criminais na Província do Espírito Santo (1853-1870). 2006. 160 f. Dissertação (Mestrado em História). Programa de Pós-Graduação em História da Universidade Federal do Espírito Santo, Vitória. 2006.

97

SOUZA, Alinaldo Faria de. Entre a reclusão e o enfrentamento: a realidade da condição feminina no Espírito Santo a partir dos autos criminais (1845-1870): desmistificando estereótipos. 2007. 143 f. Dissertação (Mestrado em História). Programa de Pós-Graduação em História da Universidade Federal do Espírito Santo, Vitória.

98

CÂMARA, Raphael Americano. Cotidiano, violência e criminalidade na comarca de Vitória/ ES, a partir de autos criminais (1841-1871). 2013. 145 f. Dissertação (Mestrado em História). Programa de Pós-Graduação em História da Universidade Federal do Espírito Santo, Vitória.

99

APE/ES. Fundo Governadoria. Série 383. Livro 202. Correspondência do delegado de polícia de Itapemirim, Antonio Nascimento e Silva, ao chefe de Polícia da Província do Espírito Santo, Antonio Thomaz de Godoy, datada de 29 de dezembro de 1855. temendo as epidemias, mesmo que o pavor do contágio fosse uma realidade, o espírito de solidariedade não desapareceu de todo. Luzia Pinto Rangel dos Santos agradecia "[...] as pessoas que visitaram e socorreram e acompanharam ao seu fallecido marido Francisco Rodrigues dos Santos, atacado da epidemia reinante no dia 2 do corrente, e fallecendo nesse mesmo dia [...]."93 0 mesmo fez Ignacio de Mello Coutinho Vieira Machado e sua mulher, D. Marcollina de Paiva Gomes dos Santos, ao agradecer a todas as pessoas que se dignaram a acompanhar os restos mortais do seu idolatrado filho, Ignacio Gomes de Mello Coutinho. ${ }^{94}$

Ao doarem dinheiro para a compra de víveres, remédios ou fazendo doações de casas para instalação de enfermarias, os moradores de diferentes localidades davam demonstração de solidariedade em frente ao mal epidêmico que os afligia.

\section{Os reflexos na economia}

Além de causar pânico e pavor, a cólera foi responsável pelo declínio econômico, com a queda na produção dos gêneros de primeira necessidade. Em correspondência do médico Manoel Gomes Bittencourt ao Governo Provincial, este relata as dificuldades vivenciadas pelos habitantes da província que passaram a ver os alimentos escassearem e os preços subirem assustadoramente: "[...] a farinha por alguma que apparece exigem preços fabulozos e a carne verde nenhuma se encontra." ${ }^{15}$

Certamente a vigília que se estabeleceu sobre as embarcações que aportavam na província, temendo-se que estas trouxessem surtos epidêmicos, e o estabelecimento de quarentenas às embarcações provenientes de portos onde a cólera já havia se manifestado contribuíam para a diminuição do fluxo do comércio por via marítima, o que impactava a economia local.

Sabemos que a maioria da população da Província do Espírito Santo vivia pobremente, garantindo o seu sustento mediante plantações de suas pequenas lavouras e criação de animais. Dentre os produtos de subsistência que eram produzidos (parte que excedia ao abastecimento interno era exportada), tínhamos mandioca, milho, arroz e feijão. Não podemos esquecer, por fim, a atividade pesqueira, como importante fonte de alimentação da população local.

Em suas pesquisas, Arion Mergár, ${ }^{96}$ Alinaldo Faria de Souza ${ }^{97}$ e Raphael Americano Câmara, ${ }^{98}$ analisando autos criminais da Província do Espírito Santo, verificaram que a grande maioria dos réus, vítimas ou testemunhas, lidavam diretamente com a agricultura, lavrando suas pequenas propriedades ou trabalhando nas poucas grandes lavouras existentes na província, como meeiros, sitiantes ou ainda a jornal, o que evidencia que a maioria da população garantia as suas sobrevivências com as fainas diárias e que essa produção, além de assegurar o sustento destes, tinha uma parte comercializada no mercado consumidor interno. 0 surto epidêmico impedia a produção, acarretando graves consequências para o sustento desses pequenos produtores, assim como provocava o desabastecimento do mercado interno, o que ajudava ainda mais para o aumento da carestia. 0 delegado de Itapemirim confirma essa assertiva, ao relatar que, com a chegada da cólera, grandes transtornos foram vividos pela população, pois a fome ia "[...] apparecendo com grande força! Há falta de gêneros de primeira necessidade." 99 Exemplificando como a carestia tomou conta dos produtos necessários ao consumo, foi publicada na imprensa local uma crítica às 
autoridades que não fiscalizavam a elevação abusiva dos preços na cidade de Vitória.

100

Correio da Victoria, f. 2, 29/nov./1855.

101

Idem, f. 2, 21/nov./1855.

102

ALEXANDRE, Jucieldo Ferreira. Quando o

"anjo exterminador" se aproxima de nós: representação sobre o cólera no Semanário Cratense o Araripe (1855-1864). 2010. $244 \mathrm{f}$. Dissertação (Mestrado em História). Programa de Pós-Graduação em História do Centro de Ciências Humanas, Letras e Artes da Universidade Federal da Paraiba, João Pessoa. 2010.

103

CARDOSO, Amâncio. As filhas da peste, fome, morte e orfandade. Sergipe, 1855-1856. Revista do Instituto Histórico e Geográfico de Sergipe, Aracaju: Instituto Histórico e Geográfico de Sergipe, Vol. 1, n. 1, 1913. p. 30.
Não basta a epidemia para nos flagellar, a falta de gêneros de primeira necessidade he tão bem um flagello. A carne verde só se vende aos amigos, e aos grandes da terra! As gallinhas são atravessadas logo na pedra do Lasaro, e se milagrosamente escapão d'ahi, são todas compradas por algum do Porto dos Padres [importante área comercial], para as revender por 4 e 5 patacas! Acuda-nos, por amor de Deos, Sr. fiscal; valha-nos por quem he, pois assim morremos à fome, se escapar-mos da bicha. ${ }^{100}$

Numa outra notícia, o tom do drama vivido na província fica mais uma vez evidenciado:

Muitas são as necessidades que soffrem a maior parte dos moradores desta povoação, por quanto além de lhes faltar meios pecuniários, experimentão a escacez dos alimentos de primeira necessidade: a farinha por alguma que appareça, exigem preços fabulozos e a carne verde nem uma se encontra. Ouvindo ao juiz de paz referido e algumas pessoas desta povoação, rezolvi mandar comprar alguns alqueires de farinha, e uma rez para distribuir pela pobreza, bem como tenho já dividido por alguns destes a quantia de duzentos e dez mil réis, da qual não exijo embolso. ${ }^{101}$

No Rio Grande do Norte e no Ceará, quando da ocorrência da cólera, fenômeno idêntico aconteceu, segundo Jucieldo Ferreira Alexandre, provocando desabastecimento e carestia, uma vez que os comerciantes passaram a rejeitar a possibilidade de comercializar seus produtos em áreas afetadas pela epidemia. Alimentos básicos na dieta da população, como farinha de mandioca, milho, carne verde (boi) e galinha, sumiram do mercado e, quando apareciam, apresentavam preço triplicado. ${ }^{102}$

Também na região do Sergipe o comércio foi desestabilizado e as feiras paralisadas: "Arrendatários, moradores, sitiantes, posseiros, jornaleiro, lavradores, compunham uma fieira de homens ceifada pela cólera, coadjuvando para o transtorno no desabastecimento, na carestia dos gêneros e na propagação da fome [...]." ${ }^{103}$

Os preços dos gêneros de primeira necessidade, como carne-seca, carne verde, farinha, milho feijão, que faziam parte dos hábitos alimentares dos populares, aumentarem. Tal impasse muitas vezes exigia que o Governo Provincial tivesse que assumir a compra desses produtos para distribui-los entre a pobreza.

\section{Considerações finais}

As doenças, desde os tempos coloniais, foram uma realidade na vida da população do Espírito Santo. No século XIX, assim como ocorreu em outras regiões do Brasil, houve um aumento significativo dos surtos epidêmicos. 0 aumento da população e a urbanização que se iniciava no País contribuíram para que as doenças se disseminassem. Combinado a esses fatores, temos, ainda, o crescimento das atividades comerciais que levava a que surtos epidêmicos pudessem ser trazidos por embarcações que aportavam nas cidades litorâneas.

Não podemos nos esquecer de que a falta de higiene da população e das cidades, a falta de medicamentos, de médicos e de hospitais, os parcos conhecimentos de Medicina, também foram fatores decisivos para a eclosão das epidemias.

As epidemias alteraram a vida cotidiana da população. A assistência aos enfermos e os rituais fúnebres foram modificados, em função do 
medo que os doentes e os mortos por surto epidêmico causavam entre os vivos, que temiam serem contagiados.

A produção de gêneros alimentícios ligados à lavoura, à pesca ou à pecuária sofreu forte impacto, pela morte ou pela paralisação das atividades das pessoas, provocando escassez de alimentos e elevação do custo de vida, resultando em penúria, em especial, para a população mais pobre economicamente.

Mas os surtos epidêmicos contribuíram também para que o Estado tivesse que tomar a dianteira no que concerne a desenvolver ações públicas em relação à saúde da população. Ampliar a vacinação, contratar mais médicos, distribuir medicamentos e viveres passaram a ser tarefas que 0 Estado chamou para si como responsabilidade. 